\title{
İkinci ürün koşullarında yetiştirilen soya bitkisinin farklı gelişme dönemlerinde tepe büyüme noktasında oluşan mekanik zararın tohum verimi ile bazı tarımsal özellikler üzerine etkileri
}

The effects of mechanical damage at different growing stage on seed yield and some agronomic characteristics of soybean plant in double crop growing conditions

\author{
Halil BAKAL ${ }^{1}$ (D), Özge BAĞIRKAN ${ }^{1}$ (D), Halis ARIOĞLU ${ }^{1}$ \\ ${ }^{1}$ Çukurova University, Faculty of Agriculture, Department of Field Crops, Adana, Turkey.
}

\section{MAKALE BILGISI / ARTICLE INFO}

Makale tarihçesi / Article history:

DOI: $\underline{10.37908 / m k u t b d .770096}$

Geliş tarihi /Received:16.07.2020

Kabul tarihi/Accepted:06.11.2020

\section{Keywords:}

Soybean, mechanical damage, seed yield, plant development period.

Corresponding author: Halil BAKAL

$\bowtie$ : hbakal@cu.edu.tr

\section{ÖZET / ABSTRACT}

Atıf / Citation: Bakal H, Bağırkan Ö, Arıoğlu H (2021) İkinci ürün koşullarında yetiştirilen soya bitkisinin farklı gelişme dönemlerinde tepe büyüme noktasında oluşan mekanik zararın tohum verimi ile bazı tarımsal özellikler üzerine etkileri. MKU. Tar. Bil. Derg. 26(1) : 117-127. DOI: 10.37908/mkutbd.770096

\section{GiRiş}

İçerdiği yüksek orandaki değerli besin maddeleri (yağ, protein, mineral maddeler ve vitaminler) nedeniyle, insan ve hayvan beslenmesinde önemli bir yere sahip olan soya, aynı zamanda, sanayi sektörü için de önemli bir hammadde kaynağını oluşturmaktadırlar. Soya, önemli bir yağ bitkisidir. Tohumlarında \% 18-24 oranında yağ bulunmaktadır. Insan vücudundaki yağ ve lipit metabolizmasını düzenleyen yağ asitlerini içermesi nedeniyle soya yağı, sağlıklı beslenme bakımından çok önemli bir gıda maddesidir. Soya yağı insan gıdası olarak kullanıldığı gibi, sanayide hammadde olarak da geniş kullanma alanlarına sahiptir. Aynı zamanda, soya tohumunda bulunan yüksek orandaki protein (\%36-42) ve proteini oluşturan çok değerli aminoasitler nedeniyle de, hayvan beslenmesinde vazgeçilmez konumda olan önemli bir yem hammaddesidir (Arıoğlu, 2014; Arıoğlu ve Güllüoğlu, 2018).

Soya bitkisel yağlı tohum üretimi bakımından dünyada önemli bir yere sahiptir. 2018 yılı verilerine göre dünya yağlı tohum üretimi 574 milyon ton olup, bunun $\% 62.7$ 'sini (360 milyon ton) soyadan karşılanmaktadır. Aynı dönemde; Türkiye'de yağlı tohum üretimi ise yaklaşık 3.8 milyon ton olup, \%3.7'lik kısmını (140 bin ton) soya tohumu oluşturmaktadır (FAO, 2019). 
Ülkemizde yaklaşık 330 bin dekarlık alanda soya ekilmektedir. Ekim alanlarının yaklaşık \%80'inin ikinci ürün ekimleri oluşturmaktadır (TÜiK, 2019).

Ekimi yapılan soya tohumları uygun sıcaklık ve nem koşullarında 4-7 gün içerisinde çimlenerek, toprak yüzeyinde yeni bitki meydana gelir. Kotiledon yapraklarının toprak yüzeyine çıkmasından hemen sonra, ortadaki büyüme noktasında birinci derecedeki iki adet basit yapraklar teşekkül eder $\left(\mathrm{V}_{0}\right)$, daha sonra ilk boğum oluşur ve üzerinde üçlü ilk ana yapraklar çıkmaya başlar $\left(V_{1}\right)$ ve vejetatif büyüme hızla devam eder $\left(V_{2} \ldots . . V n\right)$. Bitkinin büyüme modeline göre, bir taraftan büyüme devam ederken, diğer taraftan, yaprak koltuklarından yeni sürgünler (dallanma) veya çiçekler meydana gelir. Soya bitkisi, belirli bir büyüklüğe ulaştığında, çeşit özelliğine bağlı olarak, generatif devreye geçer ve çiçeklenmeye başlar ( $R$ gelişme dönemi). Soya bitkisinin büyüme ve gelişmesini etkileyen en önemli çevre faktörlerinin başında sıcaklık ve gün uzunluğu gelmektedir. Soya kısa gün bitkisidir. Gün uzunluğu arttıkça, vejetatif gelişme süresi uzar ve çiçeklenme başlangıcı önemli ölçüde gecikir. Soya çeşitlerinin gün uzunluğuna tepkileri oldukça farklı olup, gün uzunluğuna tepkilerine göre soya çeşitleri arasında farklı olgunlaşma grupları oluşur (Arıoğlu, 2014).

Toprak yüzeyine ulaşan soya bitkisinin büyüme modeli (sap kısmının büyümesi) çeşit özelliğine bağlı olarak; indeterminate (sınırsız büyüme), determinate (sınırlı büyüme) ve semideterminate (yarı sınırlı büyüme) şeklinde olmaktadır. Indeterminate sap büyüme tipinde; çiçeklenme ile birlikte sap büyümesi de devam eder. Sap büyümesi, çiçeklenme sonuna kadar devam etmektedir. Semideterminate sap büyüme tipinde; sap büyümesi kısmen sınırlıdır. Çiçeklenme ile birlikte sap büyümesi de devam etmekte, ancak, kısa süre sonra sap büyümesi durmakta ve çiçeklenme devam etmektedir. Determinate sap büyüme tipinde ise; bitki belirli bir büyüklüğe ulaştıktan sonra çiçeklenme başlamakta, çiçeklenme tam teşekkül ettikten sonra boyuna büyüme durmakta ve sap kalınlaşmaktadır (Arıoğlu, 2014). Soyada bitki boyu; çeşit, ekim sıklığı, ekim zamanı ve yetiştirme şartlarına bağlı olarak $30-180 \mathrm{~cm}$ arasında değişim göstermekte ve dallanma meydana gelebilmektedir. Yetişme süresi boyunca ortaya çıkan olumsuz hava koşulları bitkilerin büyüme ve gelişmesini çeşit özelliğine göre farklı düzeylerde etkilemektedir. Özellikle, fırtına ve dolu gibi olumsuz hava koşulları bitkilerde önemli zararlar meydana getirmektedir ve bitkilerde stres oluşmaktadır. Soya bitkisinin stres koşullarından etkilenmesi ve zarar görmesi, bitkinin etkilendiği büyüme dönemine ve sap büyüme modeline göre değişmektedir. Erken veya geç dönemde meydana gelen dolu veya fırtına zararı, bitkileri farklı şekillerde strese sokmakta ve tohum veriminin değişmesine (olumlu veya olumsuz) neden olmaktadır.

Yetişme süresi boyunca oluşan dolu zararı fiziki olup daha çok meyveler, yapraklar ve sürgünler üzerinde etkili olmaktadır. Dolu zararı; yağışın süresine şiddetine ve büyüklüğüne bağlı olarak değişkenlik göstermektedir. Dolu tanesinin iriliği ve bitkilerin genç, taze oluşu dolu zararını arttırmaktadır. Hafif dolular meyvelere ve yapraklara zarar verdiği gibi çok şiddetli dolular meyve dökümü, yaprak tahribi ve ince dallarda yaralar meydana getirmektedir. Dolu yağışları özellikle bitkilerin ileri gelişme dönemlerinde büyük zararlara neden olmakta ve verimi düşürmektedir (Asar ve ark., 2007). Bu gibi hasar durumlarında, bitkinin hangi vejetatif dönemde olduğunun bilinmesi zararın tespiti açısında oldukça önemlidir. Vejetatif dönemde oluşan tepe noktasındaki herhangi bir zararda soya bitkisi, alt kısımdaki sürgünlerden çok fazla yan dal meydana getirerek kendini toparlayabilme yeteneğinde sahiptir (Çırak ve Esendal, 2005).

Fehr ve ark. (1977), ABD'de yaptıkları bir çalışmada, $R_{2}-$ $\mathrm{R}_{7}$ arasındaki gelişme döneminde soya bitkisinin tepe büyüme noktasını kırmak veya yaprakları koparmak suretiyle mekanik zarar meydana getirmişlerdir. Neticede; tepe büyüme noktasında meydana getirilen mekanik zararın tohum veriminde \%30-40 dolaylarında, yapraklarda meydana getirilen zararın ise \%40-60 arasında değişen miktarlarda azalmaya neden olduğunu saptamışlardır. Oba ve Arığlu (2001), Yapmış oldukları bir çalışmada, farklı gelişme dönemlerinde $\left(\mathrm{V}_{4}-\mathrm{V}_{10}\right)$ soya bitkisinde meydana getirilen farklı oranlardaki mekanik zararın, tohum veriminde \%4-39 arasında değişen oranlarda azalmaya neden olduğunu bildirmişlerdir. Ayrıca, vejetatif dönemlerde $\left(V_{4}\right)$ tepe noktasında meydana getirilen zararın, verim düşüklüğüne etkisinin en az düzeyde olduğunu gözlemişlerdir.

Çırak ve Esendal (2005), soya bitkisinin büyüme ve gelişme dönemlerinde bazı çevre faktörlerin verim üzerine olumsuz etkilerinin olduğunu belirtmişlerdir. Özellikle vejetatif gelişme dönemlerinde bitkinin tepe büyüme noktasının zarar görmesi halinde (dolu ve benzeri etkiler), alt kısımlarda bulunan boğumlardaki tomurcuklardan yeni dalların (sürgün) meydana gelmesi nedeniyle, bitki üzerinde oluşan zararın olumsuz etkisinin ortadan kalktığını bildirmişlerdir. Conley ve ark. (2008), ABD'nin lowa ve Indiana eyaletlerinde yaptıkları bir çalışmada, soya bitkisinin farklı gelişme dönemlerinde $\left(V_{2}, V_{6}\right.$ ve $\left.R_{3}\right)$ bitki üzerinde farklı oranlarda mekanik zarar meydana getirilmiştir. Soya bitkisinin tepe büyüme noktasında $V_{2}$ dönemde meydana getirilen mekanik zararın, $V_{6}$ dönemine göre 
daha az etkilendiği ve \%15.9 daha fazla verim elde edildiğini (Indiana eyaletinde) bildirmişlerdir. Diğer taraftan lowa eyaletindeki denemelerde ise, $V_{2}$ döneminde meydana getirilen mekanik zararın, $V_{6}$ ve $R_{3}$ dönemlerine göre sırasıyla \%24.9 ve \%46.1 daha fazla verim elde edilmesine neden olduğunu ortaya koymuşlardır.

Çukurova bölgesinde ikinci ürün koşullarında yürütülecek olan çalışmada, farklı büyüme özelliğine sahip ve olgunlaşma grubu içerisinde yer alan soya çeşitlerinin tepe büyüme noktasında, farklı gelişme dönemlerinde oluşturulan mekanik zararın (dolu zararı benzeri) tohum verimi ile bazı tarımsal özelliklere etkisini belirlemektir.

\section{MATERYAL ve YÖNTEM}

\section{Deneme materyali}

Bu çalışmaya konu olan denemeler; 2018 ve 2019 yıllarında ve ikinci ürün koşullarında, Çukurova Üniversitesi, Ziraat Fakültesi, Tarla Bitkileri Bölümü Araştırma ve Deneme Alanında kurulup yürütülmüştür. $\mathrm{Bu}$ çalışmada; soya bitkisinin farklı vejetatif gelişme dönemlerinde, tepe noktasını kesmek suretiyle mekanik zarar meydana getirmek ve bu uygulamanın tohum verimi ile bazı tarımsal özellikler üzerine etkilerini belirlemek amaçlanmıştır. Araştırma konusu ile ilgili denemede, Türkiye'de üretimi yapılan III. ve IV. olgunlaşma gruplarında yer alan Arısoy ve Blaze soya çeşitleri materyal olarak kullanılmıştır. Arısoy çeşidi; ç.Ü. Ziraat Fakültesi Tarla Bitkileri Bölümünde ıslah edilerek tescil ettirilmiş, orta erkenci ve sınırsız büyüme (indeterminate) özelliğine sahip, yüksek verimli ve beyazsineğe (Bemisia tabaci Genn.) dayanıklı bir soya çeşididir. Blaze çeşidi ise, $A B D$ 'de ıslah edilmiş, orta geççi, yarı sınırlı (semideterminate) büyüme özelliğine sahip, yüksek verimli ve beyazsineğe orta derecede dayanıklı bir soya çeşididir.

\section{Deneme yerine ait toprak ve iklim özellikleri}

Denemenin kurulduğu topraklar Seyhan Nehrinin yan derelerinin getirdiği çok zengin alüvyonlardan oluşmuştur. Denemeni yapıldığı alana ait toprağın $\mathrm{pH}^{\prime} \mathrm{sı}$ her iki deneme yılında da 7.45-7.49 arasında olup, genellikle hafif alkali bir özellik göstermektedir. Toprağın $\mathrm{P}_{2} \mathrm{O}_{5}$ içeriği 2.8-3.0 kg da ${ }^{-1}, \mathrm{~K}_{2} \mathrm{O}$ içeriği ise $70.5-75.0 \mathrm{~kg} \mathrm{da}$ ${ }^{1}$ olarak bulunmuştur. Soya tarımı için $\mathrm{K}_{2} \mathrm{O}$ içeriği yeterli düzeyde olup, $\mathrm{P}_{2} \mathrm{O}_{5}$ ihtiyacı gübreleme ile karşılanmıştır. Toprağın kireç içeriği \%25.9-26.0 ve organik madde içeriği ise \%1.4-1.6 olarak belirlenmiştir. Denemeler her iki yılda da birbirine çok yakın yerlerde kurulduğu için, toprak yapısında yıllara göre önemli farklılıklar gözlenmemiştir.

Denemenin yürütüldüğü Adana ilinde Akdeniz iklimi etkili olmaktadır. Bu nedenle kışları ılık ve yağışlı, yazları sıcak ve kurak geçmektedir. Deneme süresince Adana iline ait bazı iklim değerleri Çizelge 1'de verilmiştir. Deneme süresince ölçülen ortama sıcaklık değerleri uzun yıllarda $21.6^{\circ} \mathrm{C}$ ile $28.7^{\circ} \mathrm{C}$ arasında değişirken 2018 yılında ortalama sıcaklık değerleri $22.9-29.7^{\circ} \mathrm{C}$ arasında, 2019 yılında ise $24.2-29.6^{\circ} \mathrm{C}$ arasında değişim göstermiştir. Uzun yıllar verilerine göre yetiştirme sürecine ait toplam yağış miktarı $92.2 \mathrm{~mm}$ iken, 2018 yılında bu yağış 92.2 $\mathrm{mm}$ ve 2019 yılında ise $64.6 \mathrm{~mm}$ olarak gerçekleşmiştir. Yağışın yetersiz olması nedeniyle, gereksinim duyulan miktar sulama ile karşılanmıştır. Hava nispi nemi ise 2018 yılında \%58.6-70.2, 2019 yılında ise \% 61.6-68.8 arasında değişim göstermiştir. Uzun yıllara göre önemli bir farklılık gözlenmemiştir.

Çizelge 1. Denemelerin yürütüldüğü 2018 ve 2019 yıllarının ve uzun yıllara (1929-2019) ait iklim verileri

Table 1. The climate conditions during the 2018-2019 growing period and long term average (1929-2019)

\begin{tabular}{lccccccccc}
\hline \multirow{2}{*}{ Aylar } & \multicolumn{3}{c}{ Ortalama Sıcaklık } & \multicolumn{3}{c}{ Toplam Yağı̧s } & \multicolumn{3}{c}{ Nisbi Nem } \\
\cline { 2 - 11 } & $\mathbf{2 0 1 8}$ & $\mathbf{2 0 1 9}$ & U.Y* & $\mathbf{2 0 1 8}$ & $\mathbf{2 0 1 9}$ & U.Y & $\mathbf{2 0 1 8}$ & $\mathbf{2 0 1 9}$ & U.Y \\
\hline Haziran & 26.4 & 27.1 & 25.6 & 27.0 & 13.8 & 20.5 & 70.2 & 68.7 & 70.2 \\
Temmuz & 29.1 & 28.4 & 28.2 & 0.0 & 28.0 & 6.2 & 69.8 & 68.8 & 67.5 \\
Ağustos & 29.7 & 29.6 & 28.7 & 0.0 & 0.0 & 5.5 & 68.8 & 68.0 & 68.5 \\
Eylül & 27.9 & 27.3 & 26.1 & 1.2 & 0.0 & 17.6 & 63.6 & 62.1 & 65.4 \\
Ekim & 22.9 & 24.2 & 21.6 & 64.0 & 22.8 & 42.4 & 58.6 & 61.6 & 60.3
\end{tabular}

U.Y: Uzun yıllar (1929-2019)

\section{Deneme yöntemi ve uygulama tekniği}

Bu deneme, Ç.Ü. Ziraat Fakültesi Tarla Bitkileri Bölümü Deneme ve Uygulama Alanında, ikinci ürün koşullarında bölünmüş parseller deneme desenine göre 3 tekrarlamalı ve her parsel 4 sıra olacak şekilde kurulmuştur. Parsellerin boyu $5 \mathrm{~m}$, sıra arası mesafe 70 $\mathrm{cm}$ ve sıra üzeri mesafe ise $4 \mathrm{~cm}$ olacak şekilde (deneme alanı $14.0 \mathrm{~m}^{2}$ ), 19 Haziran 2018 ve 22 Haziran 2019 tarihlerinde elle ekimler yapılmıştır. Ekim öncesi dekara 
25 kg DAP (\%18 N ve \%46P) gübresi elle serpilerek, diskaro ile toprağa karıştırılmıştır.

Ekim sırasında soya tohumları Bradyrhizobium japonicum bakterisi ile 1/100 oranında aşılanmıştır. Daha sonra yabancı ot durumuna göre 2-3 defa çapa yapılarak yabancı otlar kontrol altına alınmıştır. İkinci sulamadan önce dekara $15 \mathrm{~kg}$ Üre (\%46N) düşecek şekilde üst gübreleme yapılmıştır. Hastalıklarla ve zararlılarla mücadele amacıyla gerektiğinde fungusit ve insektisit uygulaması yapılmıştır. İlk çiçekler görülmeye başladığında ilk sulama, ilk sulamayı takiben, hava şartlarına bağlı olarak 12-15 gün ara ile toplamda 4-5 defa sulama yapılarak bitkilerin su ihtiyacı karşılanmıştır. Bitkilerin olgunlaşma durumuna göre; her iki yılda da Arısoy çeşidi 6 Ekim ve Blaze çeşidi ise 15 Ekim tarihinde hasat edilmişlerdir. Hasat sırasında, parsellerin orta iki sırasındaki bitkiler elle çekilmiş ve harman makinesi ile harmanlanarak tohumlar elde edilmiştir.

Farklı gelişme dönemlerinde olmak üzere, kontrol ile birlikte dört farklı uygulama yapılmıştır. Bunlar; kontrol, $V_{1}, V_{2}$ ve $V_{3}$ uygulamalarıdır. $V_{1}$ (Ana gövdede ilk gerçek yaprağın çıktığı devre), $V_{2}$ (Ana gövdede ikinci gerçek yaprağın çıktığı devre) ve $V_{3}$ (Ana gövdede üçüncü gerçek yaprağın çıktığı devre) devrelerinde olmak üzere üç farklı gelişim döneminde bitkilerin tepe noktasını keserek (makasla) mekanik zarar meydana getirilmiştir. Kontrol uygulamasında ise bitkilere hiçbir işlem yapılmamıştır.

\section{Incelenen özellikler ve yöntemi}

Bitkiler hasat olgunluğuna ulaştığında, her parselin orta iki sırasından tesadüfen 20 bitki alınmış ve alınan örnek bitkiler üzerinde gerekli ölçüm ve tartımlar yapılmıştır. Verim değerleri ise parseldeki sıraların tamamı hasat edilerek hesaplanmıştır. Bu çalışmada: bitki boyu, ilk bakla yüksekliği, dal sayısı, bakla sayısı, 1000 tohum ağırlığı, yağ oranı, protein oranı ve tohum verimi gibi önemli tarımsal özellikler Bakal ve ark. (2017) tarafından uygulanan yöntemlere göre incelenmiş ve değerlendirilmiştir. Denemeden elde edilen değerler, JMP 8.1. istatistik paket programı kullanılarak, çeşitler ana parsel, farklı dönemlerde uygulanan mekanik zarar uygulamaları alt parsel olacak şekilde bölünmüş parseller deneme desenine göre varyans analizine tabi tutulmuş. Elde edilen ortalamalar arasındaki farklılıklar ise EGF ( $p \leq$ 0.05 ) testi kullanılarak değerlendirilmiştir.

\section{BULGULAR ve TARTIŞMA}

\section{Bitki boyu}

Çizelge 2'nin incelenmesinden de görüleceği gibi, iki yıllık ortalama değerlere göre, bitki boyu değerleri bakımından çeşitler arasındaki fark, istatistiksel olarak önemli bulunmuştur. Çeşitlere ait ortalama bitki boyu değerleri $68.6-85.8 \mathrm{~cm}$ arasında değişim göstermiştir. Arısoy çeşidinde ölçülen ortalama bitki boyu değeri ( 85.8 $\mathrm{cm})$, Blaze çeşidine göre $(68.6 \mathrm{~cm})$ daha yüksek bulunmuştur. Arısoy çeşidi indeterminate, Blaze çeşidi ise semideterminate büyüme özelliğine sahip olduğu için, Arısoy çeşidinde bitki boyu daha uzun olmuştur. Ayrıca, genetik özelliği bakımından da Blaze çeşidi, Arısoy göre daha kısa boyludur. Yıldırım ve illker (2018), yürüttükleri bir denemede, soyada bazı çeşit ve hatların ortalama bitki boyu değerlerinin $63.05-94.85 \mathrm{~cm}$ aralığında değiştiğini bildirmişlerdir. Ele alınan bitki boyu değerleri bakımından çeşitler arasında oluşan farklılıklar, çeşitlerin genetik özelliklerinin farklı olması ile birlikte biyotik ve abiyotik stres koşullarından farklı şekillerde etkilenmelerinden kaynaklanabilmektedir. Güllüoğlu ve ark. (2016), ikinci ürün koşullarında Atakişi soya çeşidinde bitki boyunun 82.1-95.5 cm arasında değişim gösterdiğini bildirmişlerdir. Ayrıca, Bakal ve ark. (2017) yaptıkları bir çalışmada, bitki boyu, Arısoy çeşidinde $108.8 \mathrm{~cm}$, Blaze çeşidinde ise $93.6 \mathrm{~cm}$ olarak ölçülmüştür.

Soya bitkisinin tepe noktasında meydana getirilen mekanik zarar, çeşitlerin bitki boyu üzerine önemli düzeyde etkili olmuştur. Yapılan uygulamalara göre, iki yıllık ortalama bitki boyu değerleri Arısoy çeşidinde 76.2$92.1 \mathrm{~cm}$, Blaze çeşidinde ise $58.1-81.7 \mathrm{~cm}$ arasında değişim göstermiştir. Iki yıllık ortalama değerlere göre, en yüksek bitki boyu Arısoy çeşidinde $92.1 \mathrm{~cm}$ ve Blaze çeşidinde ise $81.7 \mathrm{~cm}$ olarak, kontrol parsellerindeki bitkilerde ölçülmüştür. Gelişmenin ileri dönemlerinde meydana getirilen mekanik zarar, her iki çeşitte de bitki boyunun kısalmasına neden olmuştur. $V_{3}$ döneminde meydana getirilen mekanik zararda ortalama bitki boyunun Arısoy çeşidinde $76.2 \mathrm{~cm}$ iken, bu değer Blaze çeşidinde $58.1 \mathrm{~cm}$ olmuştur. Bitki boyunda meydana gelen kısalma Arısoy çeşidinde \%17.3 iken, bu değer, Blaze çeşidinde \%28.9 olmuştur. Arısoy çeşidi indeterminate büyüme özelliğine sahip olduğu için, tepe noktasında zarar meydana gelmesi halinde dahi, büyüme az da olsa devam edebilmektedir. Çeşitlere ait iki yıllık ortalama bitki boyu değeri uygulamalara göre 67.2-86.9 $\mathrm{cm}$ arasında değişim göstermiş olup, en yüksek bitki boyu değerleri, herhangi bir mekanik zarar verilmeyen kontrol uygulamalarından $(86.9 \mathrm{~cm})$ elde edilirken; bunu sırasıyla $V_{1}(79.8 \mathrm{~cm}), V_{2}(75.1 \mathrm{~cm})$ ve $V_{3}(67.2 \mathrm{~cm})$ uygulamaları izlemiştir (Çizelge 2). $V_{3}$ döneminde meydana getirilen mekanik zarar, bitki boyunda ortalama \%11.9'luk kısalmaya neden olmuştur. Gelişmenin ileri dönemlerinde $\left(V_{2}\right.$ ve $\left.V_{3}\right)$ bitkilerin tepe büyüme noktasında meydana gelen zarar, genel olarak bitkilerde boylanmayı durdurmakta ve yanlara doğru 
büyümeyi artırmaktadır. Bu nedenle, $V_{3}$ döneminde yapılan uygulamalarda bitki boyu en kısa olmuştur. Camery ve Weber (1953), soyada dolu zararının etkilerini inceledikleri araştırmalarında, yapay olarak yarattıkları zarar sonucunda, bitki boyunun \%4 kadar kısaldığını saptamışlardır. Bitki boyuna etkileri bakımından, çeşitler $\mathrm{x}$ uygulamalar arasındaki ilişki istatistiksel olarak \%5 düzeyinde önemli bulunmuştur. Çizelge 2'nin incelenmesinden de görüleceği gibi, iki yıllık ortalama değerlere göre, en yüksek bitki boyu Arısoy çeşidinde ve kontrol parsellerinde, en kısa bitki boyu Blaze çeşidinde ve $V_{3}$ uygulaması yapılan parsellerdeki bitkilerde ölçülmüştür.

\section{ilk bakla yüksekliği}

İki yıllık ortalama değerlere göre, ilk bakla yüksekliği değerleri bakımından çeşitler arasındaki fark, istatistiksel olarak önemli bulunmuştur. Çeşitlere ait ortalama ilk bakla yüksekliği değerleri 13.3-16.5 cm arasında değişim göstermiştir. Arısoy çeşidinde ölçülen ortalama ilk bakla yüksekliği değeri $(16.5 \mathrm{~cm})$, Blaze çeşidine göre $(13.3 \mathrm{~cm})$ daha yüksek bulunmuştur (Çizelge 2). Arısoy çeşidinde bitki boyu daha uzun olduğu için, ilk baklaların daha yukarıdan tutmasına neden olmuştur. Illk bakla yüksekliği değerleri bakımından çeşitler arasında oluşan farklııklar, çeşitlerin genetik özelliklerinin farklı olması ve farklı uygulamalara karşı farklı tepkiler vermesinden ileri gelmektedir. Güllüoğlu ve ark. (2016), ikinci ürün koşullarında Atakişi soya çeşidinde ilk bakla yüksekliğinin 15.0-18.4 cm arasında değişim gösterdiğini bildirmişlerdir. Ayrıca, Bakal ve ark. (2017) ikinci ürün koşullarında yaptıkları bir çalışmada, ilk bakla yüksekliği, Arısoy çeşidinde $20.6 \mathrm{~cm}$, Blaze çeşidinde ise $15.0 \mathrm{~cm}$ olarak ölçülmüştür.

Soya bitkisinin tepe noktasında meydana getirilen mekanik zarar, çeşitlerin ilk bakla yüksekliği üzerine önemli düzeyde etkili olmuştur. Yapılan uygulamalara göre, iki yıllık ortalama ilk bakla yüksekliği değerleri Arısoy çeşidinde 13.9-18.3 cm, Blaze çeşidinde ise 12.0$14.3 \mathrm{~cm}$ arasında değişim göstermiştir. İki yıllık ortalama değerlere göre, en yüksek ilk bakla yüksekliği Arısoy çeşidinde $18.3 \mathrm{~cm}$ ve Blaze çeşidinde ise $14.3 \mathrm{~cm}$ olarak, kontrol parsellerindeki bitkilerde ölçülmüştür. Gelişmenin ileri dönemlerinde meydana getirilen mekanik zarar, her iki çeşitte de ilk bakla yüksekliğinin kısalmasına neden olmuştur. $V_{3}$ döneminde meydana getirilen mekanik zararda ortalama ilk bakla yüksekliği Arısoy çeşidinde $13.9 \mathrm{~cm}$ iken, bu değer Blaze çeşidinde $12.0 \mathrm{~cm}$ olmuştur. Çeşitlere ait iki yıllık ortalama ilk bakla yüksekliği değeri uygulamalara göre $12.9-16.3 \mathrm{~cm}$ arasında değişim göstermiş olup, en yüksek ilk bakla yüksekliği değerleri, herhangi bir mekanik zarar verilmeyen kontrol uygulamalarından $(16.3 \mathrm{~cm})$ elde edilirken; bunu sırasıyla $V_{1}(15.5 \mathrm{~cm}), V_{2}(14.9 \mathrm{~cm})$ ve $V_{3}$ $(12.9 \mathrm{~cm})$ uygulamaları izlemiştir (Çizelge 2). $V_{3}$ döneminde meydana getirilen mekanik zarar, ilk bakla yüksekliğinde ortalama $\% 20.8^{\prime}$ lik kısalmaya neden olmuştur. Gelişmenin ileri dönemlerinde $\left(V_{2}\right.$ ve $\left.V_{3}\right)$ bitkilerin tepe büyüme noktasında meydana gelen zarar, genel olarak bitkilerde boylanmayı durdurmakta ve ilk baklalar toprağa daha yakın oluşmaktadır. İlk bakla yüksekliğine etkileri bakımından, çeşit $\mathrm{x}$ uygulamalar arasındaki ilişki istatistiksel olarak \%5 düzeyinde önemli bulunmuştur. Çizelge 2'nin incelenmesinden de görüleceği gibi, iki yıllık ortalama değerlere göre, en yüksek ilk bakla yüksekliği Arısoy çeşidinde ve kontrol parsellerinde $(16.3 \mathrm{~cm})$, en kısa ilk bakla yüksekliği Blaze çeşidinde ve $V_{3}$ uygulaması yapılan $(12.0 \mathrm{~cm})$ parsellerdeki bitkilerde ölçülmüştür. Oba ve Arıŏlu (2001), soya bitkisine dolu benzeri mekanik zarar vererek etkilerini incelediği araştırmada, yapay zarar sonucunda oluşan en yüksek ilk bakla yüksekliği değeri $13.9 \mathrm{~cm}$ ile $\mathrm{V}_{10}$ ( \%25 yaprak) uygulamasından elde edilirken, en düşük değer $10.5 \mathrm{~cm}$ ile $V_{4}$ (\%5 yaprak + tepe) uygulamasından elde edilmiştir.

\section{Dal sayısı}

Çizelge 3'ün incelenmesinden de görüleceği gibi, yapılan uygulamalara göre, bitki başına dal sayısı değerleri bakımından çeşitler arasındaki farklılık istatistiksel olarak önemsiz bulunmuştur. İki yıllık ortalama değerlere göre, bitki başına dal sayısı Arısoy çeşidinde 3.1 adet/bitki, Blaze çeşidinde ise 3.3 adet/bitki olarak bulunmuştur. Blaze çeşidinde elde edilen dal sayısının değeri, Arısoy çeşidine göre önemsiz de olsa yüksek bulunmuştur. Genelde, semideterminate çeşitlerde dallanma, indeterminate çeşitlere göre daha fazla olmaktadır. Güllüoğlu ve ark. (2016), ikinci ürün koşullarında Atakişi soya çeşidinde dal sayısının 2.67-3.13 adet/bitki arasında değişim gösterdiğini bildirmişlerdir. Ayrıca, Bakal ve ark. (2017) ikinci ürün koşullarında yaptıkları bir çalışmada, ortalama dal sayısını, Arısoy çeşidinde 2.5 adet/bitki, Blaze çeşidinde ise 2.0 adet/bitki olarak bulmuşlardır.

Soya bitkisinin tepe noktasında meydana getirilen mekanik zarar, çeşitlerin dal sayısı değerleri üzerine önemli düzeyde etkili olmuştur. Yapılan uygulamalara göre, iki yıllık ortalama bitki başına dal sayısı değerleri Arısoy çeşidinde 1.8-4.1adet/bitki, Blaze çeşidinde ise 2.1-3.8 adet/bitki arasında değişim göstermiştir. İki yıllık ortalama değerlere göre, en yüksek dal sayısı değeri Arısoy çeşidinde 4.1 adet/bitki ve Blaze çeşidinde ise 3.8 adet/bitki olarak, $V_{3}$ uygulaması yapılan parsellerindeki bitkilerden elde edilmiştir (Çizelge 3 ). Soya bitkisinin tepe büyüme noktasında meydana gelen zarar, bitkilerin 
ana saptaki boylanmayı engellemekte, alt boğumlarda bulunan tomurcukların sürmesi ile birlikte oluşan dal sayısı artmaktadır. İki yıllık ortalama değerlere göre, çeşitlere ait ortalama dal sayısı 1.9-3.9 adet/bitki arasında değişim göstermiştir.

Zararın meydana geldiği dönemde, bitki üzerinde ne kadar çok boğum bulunur ise oluşacak dal sayısı da o kadar fazla olmaktadır. Hiçbir uygulamanın yapılmadığı bitkilerde oluşan ortalama dal sayısı değeri çeşitlerin ortalamasına göre 1.9 adet/bitki iken, $V_{1}$ döneminde yapılan uygulamadaki oluşan dal sayısı 3.4 adet/bitkiye, $V_{2}$ döneminde 3.5 adet/bitkiye ve $V_{3}$ döneminde ise 3.9 adet/bitkiye yükselmiştir (Çizelge 3 ). Bu değerlerden de görüleceği üzere, tepe noktasında zararın meydana geldiği dönemde, bitki üzerindeki boğum sayısı arttıkça, oluşan dal sayısı da artmıştır. Bu nedenle de bitki başına en fazla dal sayısı $V_{3}$ uygulanan parsellerdeki bitkilerden elde edilmiştir. Soya bitkisi vejetatif gelişme döneminde iken, dolu veya şiddetli rüzgar gibi etkenlerle bitki tepe noktası zarar gördüğünde, alt kısımlardaki yaprak koltuklarında bulunan sürgünlerin gelişerek çok sayıda yan dal meydana getirdiğini ve böylece yaprak koltuklarında en az bir tane sürgün kaldığı müddetçe dolu ve benzeri zararlardan sonra soyanın tüm vejetatif aksamını yeniden oluşturabilme kabiliyetinde olduğunu bildirmişlerdir (Çırak ve Esendal, 2005). İki yıllık ortalama değerlere göre, bitki başına dal sayısına etkileri bakımından, çeşit $x$ uygulamalar arasındaki ilişki istatistiksel olarak önemsiz bulunmuştur.

Çizelge 2. Soya bitkisinin tepe büyüme noktasında farklı gelişme dönemlerinde meydana getirilen mekanik zararın, çeşitlere göre bitki boyu ve ilk bakla yüksekliğine etkilerine ilişkin iki yıllık ortalama değerler ve EGF(\%5)'e göre oluşan gruplar

Table 2. Effects of mechanical damage of the soybean plant in different growth periods at the peak growth point belonging to plant height and the lowest pod height in two years average values groups formed according to the mean values obtained and LSD (5\%)

\begin{tabular}{|c|c|c|c|c|c|c|}
\hline \multirow{3}{*}{ Uygulamalar (B) } & \multicolumn{3}{|c|}{ Bitki boyu $(\mathrm{cm})$} & \multicolumn{3}{|c|}{ illk bakla yüksekliği (cm) } \\
\hline & \multicolumn{2}{|c|}{ Çeşitler (A) } & \multirow{2}{*}{ Ort. (B) } & \multicolumn{2}{|c|}{ Çeşitler (A) } & \multirow{2}{*}{ Ort. (B) } \\
\hline & Arisoy & Blaze & & Arisoy & Blaze & \\
\hline Kontrol & $92.1 \mathrm{a}$ & $81.7 \mathrm{~d}$ & $86.9 \mathrm{~A}$ & $18.3 \mathrm{a}$ & $14.3 \mathrm{c}$ & $16.3 \mathrm{~A}$ \\
\hline$V_{1}$ & $88.9 \mathrm{~b}$ & $70.7 \mathrm{f}$ & 79.8 B & $17.1 \mathrm{~b}$ & $13.9 \mathrm{c}$ & $15.5 \mathrm{~B}$ \\
\hline $\mathbf{V}_{2}$ & $86.2 \mathrm{c}$ & $64.1 \mathrm{~g}$ & $75.1 \mathrm{C}$ & $16.6 \mathrm{~b}$ & $13.2 \mathrm{~d}$ & $14.9 \mathrm{C}$ \\
\hline$V_{3}$ & $76.2 \mathrm{e}$ & $58.1 \mathrm{~h}$ & $67.2 \mathrm{D}$ & $13.9 \mathrm{~cd}$ & $12.0 \mathrm{e}$ & $12.9 \mathrm{D}$ \\
\hline Ort.(A) & $85.8 \mathrm{~A}$ & $68.6 \mathrm{~B}$ & & $16.5 \mathrm{~A}$ & $13.3 \mathrm{~B}$ & \\
\hline
\end{tabular}

Ort.: Ortalama; A:Çeşit; B: Uygulamalar; AxB: Çeşit x Uygulama; Ö.D.: Önemli değil.

\section{Bakla sayısı}

İki yıllık ortalama değerlere göre, bitki başına bakla sayısı değerleri bakımından çeşitler arasındaki fark, istatistiksel olarak önemli bulunmamıştır. Çeşitlere ait ortalama bakla sayısı değerleri 67.2-69.0 adet/bitki arasında değişim göstermiştir. Arısoy çeşidinde bitki başına ortalama bakla sayısı (67.2 adet/bitki), Blaze çeşidine göre (69.0 adet/bitki) daha az bulunmuştur. Genelde, soya bitkisinde dallanma arttıkça, bitki başına bakla sayısı da artmaktadır. Blaze çeşidi Arısoy çeşidine göre daha fazla dallandığı için, bitki başına bakla sayısı Blaze çeşidinde daha fazla olmuştur. Güllüoğlu ve ark. (2016), ikinci ürün koşullarında Atakişi soya çeşidinde bitki başına bakla sayısının 60.8-61.3 adet/bitki arasında değişim gösterdiğini bildirmişlerdir. Ayrıca, Bakal ve ark. (2017) ikinci ürün koşullarında yaptıkları bir çalışmada, ortalama bitki başına bakla sayısını, Arısoy çeşidinde 50.3 adet/bitki, Blaze çeşidinde ise 45.2 adet/bitki olarak bulmuşlardır. Onat ve ark. (2017) ise bitki başına bakla sayısının Arısoy çeşidinde 31.0-45.0 adet/bitki arasında, Blaze çeşidinde ise 34.0-54.4 adet/bitki arasında değişim gösterdiğini bildirmişlerdir.

Çizelge 3'ün incelenmesinden de görüleceği gibi, soya bitkisinin tepe noktasında meydana getirilen mekanik zarar, çeşitlerin bitki boyu üzerine önemli düzeyde etkili olmuştur. Yapılan uygulamalara göre, iki yıllık ortalama bitki başına bakla sayısı değerleri Arısoy çeşidinde 49.281.0 adet/bitki, Blaze çeşidinde ise 62.1-77.4 adet/bitki arasında değişim göstermiştir. iki yıllık ortalama değerlere göre, en fazla bakla sayısı Arısoy (81.0 adet/bitki) ve Blaze (77.4 adet/bitki) çeşitlerinde, $V_{1}$ döneminde uygulama yapılan parsellerindeki bitkilerden elde edilmiştir. Bu dönemde $\left(V_{1}\right)$ yapılan uygulamalar sonuncunda Arısoy çeşidindeki bitki başına oluşan bakla sayısı, kontrole göre \%64.6 oranında artarken, Blaze çeşidinde bu artış \%10.7 dolaylarında kalmıştır. Çeşitlere ait iki yıllık ortalama bakla sayısı değeri uygulamalara göre 59.6-79.2 adet/bitki arasında değişim göstermiş 
olup, en yüksek bitki başına bakla sayısı değerleri, sırasıyla $V_{1}$ (79.2 adet/bitki) ve $V_{2}$ (68.7 adet/bitki) dönemlerinde yapılan uygulamalarından elde edilmiştir (Çizelge 3). $V_{1}$ döneminde (erken dönemde) bitkilerin tepe büyüme noktalarında mekanik zarar meydana getirildiğinde, tepe noktasının hemen altındaki ilk boğumdaki sürgünler sürmeye başlar ve oluşan dallar hızlıca büyürler. Kontrole göre, $V_{1}$ döneminde zarar gören bitkilerdeki dal sayısı daha fazla olduğu için, oluşan bakla sayısı da fazla olmaktadır. Gelişmenin ileri dönemlerindeki yapılan uygulamalarda dal sayısı artmasına rağmen, dallanmanın geç kalması nedeniyle, $V_{1}$ dönemine göre daha az sayıda bakla oluşmaktadır. Oba (1996), soya bitkisine dolu benzeri mekanik zarar vererek etkilerini incelediği araştırmada, yapay zarar sonucunda en düşük bakla sayısı değeri $V_{10}$ (\%100 yaprak) uygulamasından elde edilmiştir. En yüksek bakla sayısı değeri 55.13 adet/bitki ile kontrol uygulamasından elde edilirken bunu 54.40 adet/bakla ile $\mathrm{V}_{4}$ (\%5 yaprak + tepe) uygulamasının takip ettiği bildirilmiştir. Bakla sayısına etkileri bakımından, çeşitler $\mathrm{x}$ uygulamalar arasındaki ilişki istatistiksel olarak \%5 düzeyinde önemli bulunmuştur. Çizelge 3'ün incelenmesinden de görüleceği gibi, iki yıllık ortalama değerlere göre, en yüksek bakla sayısı Arısoy çeşidinde ve $\mathrm{V}_{1}$ uygulaması yapılan parsellerdeki bitkilerde ( 81.0 adet/bitki), en az bakla sayısı ise yine Arısoy çeşidinde ve hiçbir uygulama yapılmayan parsellerdeki bitkilerde (49.2 adet/bitki) saptanmıştır.

Çizelge 3. Soya bitkisinin tepe büyüme noktasında farklı gelişme dönemlerinde meydana getirilen mekanik zararın, çeşitlere göre dal sayısı ve bakla sayısına etkilerine ilişkin iki yıllık ortalama değerler ve EGF(\%5)'e göre oluşan gruplar

Table 3. Effects of mechanical damage of the soybean plant in different growth periods at the peak growth point belonging to branch and pod number per plant in two years average values groups formed according to the mean values obtained and LSD (5\%)

\begin{tabular}{|c|c|c|c|c|c|c|}
\hline \multirow{3}{*}{ Uygulamalar (B) } & \multicolumn{3}{|c|}{ Dal Sayısı (adet bitki ${ }^{-1}$ ) } & \multicolumn{3}{|c|}{ Bakla Sayısı (adet bitki ${ }^{-1}$ ) } \\
\hline & \multicolumn{2}{|c|}{ Çeşitler (A) } & \multirow{2}{*}{ Ort. (B) } & \multicolumn{2}{|c|}{ Çeşitler (A) } & \multirow{2}{*}{ Ort. (B) } \\
\hline & Arisoy & Blaze & & Arısoy & Blaze & \\
\hline Kontrol & 1.8 & 2.1 & $1.9 \mathrm{C}$ & $49.2 \mathrm{~g}$ & $69.9 \mathrm{~d}$ & $59.6 \mathrm{D}$ \\
\hline $\mathbf{v}_{1}$ & 3.2 & 3.6 & $3.4 \mathrm{~B}$ & $81.0 \mathrm{a}$ & $77.4 \mathrm{~b}$ & $79.2 \mathrm{~A}$ \\
\hline $\mathbf{V}_{2}$ & 3.3 & 3.7 & $3.5 \mathrm{~B}$ & $70.5 \mathrm{c}$ & $66.8 \mathrm{e}$ & $68.7 \mathrm{~B}$ \\
\hline $\mathbf{V}_{3}$ & 4.1 & 3.8 & $3.9 \mathrm{~A}$ & $68.1 \mathrm{~d}$ & $62.1 \mathrm{f}$ & $65.1 \mathrm{C}$ \\
\hline Ort.(A) & 3.1 & 3.3 & & 67.2 & 69.0 & \\
\hline
\end{tabular}

EGF (\%5) A: Ö.D.; B: 0.19; AxB: Ö.D.

A: Ö.D; B: 0.70; AxB: 0.99

Ort.: Ortalama; A:Çeşit; B: Uygulamalar; AxB: Çeşit x Uygulama; Ö.D.: Önemli değil.

\section{0 tohum ağırlığı}

Çizelge 4'ün incelenmesinden de görüleceği gibi, farklı uygulamalara göre denemeye alınan soya çeşitlerine ait 1000 tohum ağırlığı değerleri 160.0-155.2 g arasında değişim göstermiştir. İki yıllık ortalama değerlere göre, 1000 tohum ağırlığı değerleri bakımından çeşitler arasındaki fark, istatistiksel olarak önemli bulunmuştur. iki yıllık ortalamalara göre Arısoy çeşidine ait 1000 tohum ağırlığı değerleri (160.0 g), Blaze çeşidine (155.2 g) göre daha yüksek bulunmuştur. 1000 tohum ağırlığı değerleri bakımından çeşitler arasında ortaya çıkan farklılık, çeşitlerin genetik yapılarının farklı olmasından ve değişik uygulamalara karşı tepkilerinin farklı olmasından kaynaklanmaktadır. Güllüoğlu ve ark. (2016), ikinci ürün koşullarında Atakişi soya çeşidinde 1000 tohum ağırlığının 136.6-144.8 g arasında değiş̧im gösterdiğini bildirmişlerdir. Ayrıca, Bakal ve ark. (2017) ikinci ürün koşullarında yaptıkları bir çalışmada, ortalama 1000 tohum ağırlığını, Arısoy çeşidinde 151.3 g, Blaze çeşidinde ise $151.2 \mathrm{~g}$ olarak bulmuşlardır. Onat ve ark. (2017) ise, yaptıkları bir çalışmada, 1000 tohum ağırlığının Arısoy çeşidinde 167-177 g, Blaze çeşidinde ise 159-166 g arasında değişim gösterdiğini bildirmişlerdir.

Soya bitkisinin tepe noktasında meydana getirilen mekanik zarar, çeşitlerin 1000 tohum değerleri üzerine önemli düzeyde etkili olmuştur. Yapılan uygulamalara göre, iki yıllık ortalama 1000 tohum ağırlığı değerleri Arısoy çeşidinde 157.1-161.5 g, Blaze çeşidinde ise 152.0-160.1 g arasında değişim göstermiştir. İki yıllık ortalama değerlere göre, en yüksek 1000 tohum ağırlığı değeri Arısoy çeşidinde $161.5 \mathrm{~g}$ ve Blaze çeşidinde ise $160.1 \mathrm{~g}$ olarak, kontrol parsellerinden elde edilmiştir (Çizelge 4).

Her iki soya çeşidinde de, bitkide meydana getirilen mekanik zararın dönemi geciktirildikçe, elde edilen tohumların 1000 tane ağırlığında önemli düzeyde azalmalar meydana gelmiştir. íki yıllık ortalama değerlere göre, yapılan farklı uygulamalardan elde edilen 
ortalama 1000 tane ağırlığı 154.5-160.8 g arasında değişim göstermiştir. Bitkilere yapılan uygulamaların zamanı geciktirildikçe, tohumların 1000 tane ağırlığında önemli miktarda azalmalar meydana gelmiştir. íki yıllık ortalama değerlere göre, kontrol parsellerinden elde edilen ortalama 1000 tohum ağırlığı $160.8 \mathrm{~g}$ iken, bu değer $V_{1}$ uygulamasında $158.9 \mathrm{~g}, V_{2}$ uygulamasında $156.1 \mathrm{~g}$ ve $V_{3}$ uygulamasında ise $154.5 \mathrm{~g}$ olarak saptanmıştır (Çizelge 4). Bu değerlerden de görüleceği gibi, 1000 tane ağırlığı en düşük $V_{3}$ uygulaması yapılan parsellerden elde edilmiştir. Bitkilerde yapılan uygulamaların zamanı geciktirildikçe $\left(V_{1}\right.$ 'den $\left.V_{3}{ }^{\prime} \mathrm{e}\right)$, bitkilerin kendini erken dönemde yenileyememesi (sürgün/dal oluşumu) ve bakla oluşumunun gecikmesi nedeniyle, bakla içerisindeki tohumların yeterince gelişememekte ve küçük kalmaktadır. Bu nedenle tohumların 1000 tane ağırlığı düşük olmaktadır. 1000 tohum ağırlı̆ına etkileri bakımından, çeşitler $\mathrm{x}$ uygulamalar arasındaki ilişki istatistiksel olarak \%5 düzeyinde önemli bulunmuştur. Çizelge 4'ün incelenmesinden de görüleceği gibi, iki yıllık ortalama değerlere göre, en yüksek 1000 tane ağırlığı Arısoy çeşidinde ve kontrol parsellerindeki bitkilerde (161.5 g)), en düşük ise Blaze çeşidinde ve $V_{3}$ uygulaması yapılan parsellerdeki bitkilerden (152.0 g) elde edilmiştir. Bu çalışmada elde edilen bulgular, Camery ve Weber (1953)'in bulguları ile de desteklenmektedir.

\section{Tohum verimi}

Çizelge 4'ün incelemesinden de görüleceği gibi, iki yıllık ortalama değerlere göre denemeye alınan soya çeşitlerine ait dekara tohum verimi değerleri 410.6$465.9 \mathrm{~kg} \mathrm{da}^{-1}$ arasında değişim göstermiştir. İki yıllık ortalama değerlere göre, tohum verimi bakımından çeşitler arasındaki fark, istatistiksel olarak önemli bulunmuştur. İki yıllık ortalamalara göre Arısoy çeşidine ait ortalama tohum verimi değerleri (465.9 $\left.\mathrm{kg} \mathrm{da}^{-1}\right)$, Blaze çeşidine (410.6 kg da-1) göre daha yüksek bulunmuştur. Dekara tohum verimi değerleri bakımından çeşitler arasında ortaya çıkan farklııı, çeşitlerin genetik yapılarının farklı olmasından ve değişik uygulamalara karşı tepkilerinin farklı olmasından ileri gelmektedir. Ayrıca, Blaze çeşidinin beyazsinek zararlısından etkilenmesi ve ilk gelişme döneminde demir eksikliğine karşı hassas olması, tohum verimini olumsuz etkilemiştir. Bakal ve ark. (2017) ikinci ürün koşullarında yaptıkları bir çalışmada, ortalama tohum verimini Arısoy çeşidinde $466.7 \mathrm{~kg} \mathrm{da}^{-1}$, Blaze çeşidinde ise $401.6 \mathrm{~kg} \mathrm{da}^{-1}$ olarak bulmuşlardır. Onat ve ark. (2017), ikinci ürün koşullarında dekara tohum veriminin Arısoy çeşidinde $354.7-512.1 \mathrm{~kg} \mathrm{da}^{-1}$, Blaze çeşidinde ise $303.8-471.9 \mathrm{~kg}$ $\mathrm{da}^{-1}$ arasında değişim gösterdiğini bildirmişlerdir.
Soya bitkisinin tepe noktasında meydana getirilen mekanik zarar, çeşitlerin tohum verimi değerleri üzerine önemli düzeyde etkili olmuştur. Yapılan uygulamalara göre, iki yıllık ortalama tohum verimi değerleri Arısoy çeşidinde 435.8-518.8 $\mathrm{kg} \mathrm{da}^{-1}$, Blaze çeşidinde ise 389.3 $428.2 \mathrm{~kg} \mathrm{da}^{-1}$ arasında değişim göstermiştir. Dekara en yüksek tohum verimi her iki çeşitte de $V_{1}$ döneminde uygulama yapılan parsellerden elde edilmiştir (Çizelge 4). Arısoy çeşidinde $V_{1}$ uygulamasından elde edilen tohum verim, kontrole göre \%19.0 oranında artarken, Blaze çeşidinde bu artış yok denecek kadar az olmuştur (\%0.6). Arısoy çeşidi indeterminate büyüme özelliğine sahip olduğu için, tepe büyüme noktasında zarar meydana gelmesi halinde, alt kısımda bulunan boğumlardaki tomurcuklar kısa zamanda yeni sürgünler (dallar) meydana getirmektedir. Diğer bir ifadeyle, bitkinin gelişmesinde çok büyük bir aksama olmamaktadır. Ancak, gelişmenin ileri dönemlerinde meydana gelen zararın olumsuz etkisi, $V_{1}$ dönemine göre daha fazla olmaktadır. Arısoy çeşidinde yapılan tüm uygulamalarda, kontrole göre önemli miktarda verim artışı elde edilirken, Blaze çeşidinde azalma gözlenmiş̧ir. Blaze çeşidinin, Arısoy çeşidine göre daha geç̧i olması ve indeterminate büyüme özelliğine sahip olması gibi nedenlerden dolayı, ileriki dönemlerde yapılan uygulamalarda bitkinin kendisini yenilemesi (yeni sürgünlerin oluşması) gecikmekte, bu da tohum veriminin düşmesine neden olmaktadır. İki yıllık ortalama değerlere göre farklı uygulamalardan elde edilen ortalama tohum verimi değeri 414.4-473.5 kg da ${ }^{1}$ arasında değişim göstermiştir. Kontrol parsellerinden elde edilen ortalama tohum verimi $430.7 \mathrm{~kg} \mathrm{da}^{-1} \mathrm{iken}$, bu değer $V_{1}$ uygulamasında $473.5 \mathrm{~kg} \mathrm{da}^{-1}, \mathrm{~V}_{2}$ uygulamasında $434.4 \mathrm{~kg} \mathrm{da}^{-1}$ ve $V_{3}$ uygulamasında ise $414.4 \mathrm{~kg} \mathrm{da}^{-1}$ olmuştur. Dekara en yüksek tohum verimi $V_{1}$ uygulanan parsellerden elde edilmiştir. $V_{1}$ uygulamasından elde edilen tohum verimi artışı, kontrole göre (\%9) olmuştur (Çizelge 4).

Soyada, tohum verimi $=$ birim alandaki bitki sayısı $\mathrm{x}$ bitki başına bakla sayısı $x$ bakla başına tohum sayısı $x$ tohumun 1000 tane ağırlığı şeklinde ifade edilmektedir (Aslam ve ark. (1993). Çizelge 3'den de görüleceği gibi, bitki başına ortalama bakla sayısı en yüksek $V_{1}$ uygulanan parsellerdeki bitkilerden elde edilmiştir. Ayrıca, bu uygulamada 1000 tohum ağırlığı değerleri de oldukça yüksek olmuştur. Bu nedenlerden dolayı dekara en yüksek tohum verimi $V_{1}$ uygulaması yapılan parsellerden elde edilmiştir. Dekara tohum verimine etkileri bakımından, çeşitler $x$ uygulamalar arasındaki ilişki istatistiksel olarak $\% 5$ düzeyinde önemli bulunmuştur. Çizelge 4'ün incelenmesinden de görüleceği gibi, iki yıllık ortalama değerlere göre, en yüksek tohum verimi Arısoy 
çeşidinde ve $V_{1}$ uygulaması yapılan parsellerden (518.8 $\mathrm{kg} \mathrm{da}^{-1}$ ), en düşük ise Blaze çeşidinde ve $V_{3}$ uygulaması yapılan parsellerden ( $\left.389.3 \mathrm{~kg} \mathrm{da}^{-1}\right)$ elde edilmiştir.

Çırak ve Esendal (2005), soya bitkisinin büyüme ve gelişme dönemlerinde bazı çevre faktörlerin verim üzerine olumsuz etkilerinin olduğunu belirtmişlerdir. Özellikle vejetatif gelişme dönemlerinde bitkinin tepe büyüme noktasının zarar görmesi halinde (dolu ve benzeri etkiler), alt kısımlarda bulunan boğumlardaki tomurcuklardan yeni dalların (sürgün) meydana gelmesi nedeniyle, bitki üzerinde oluşan zararın olumsuz etkisinin ortadan kalktığını bildirmişlerdir. Soya bitkisinde meydana gelen mekanik zararın, tohum verimi üzerine etkilerinin ortaya konulmaya çalışıldığı bu çalışmadan elde edilen bulgular, Teigen ve ark. (1975), Fehr ve ark. (1977), Tanner ve Hume (1978), Fehr ve Hicks (1983), Malone ve Caviness (1985), Hintz ve Fehr (1990), Arıoğlu (1991), Oba ve Arıoğlu (2001), Conley ve ark., (2008), Lee ve Zarnstorff (2012) ve Owen ve Emerson (2013)'nın bulguları ile de desteklenmektedir.

Çizelge 4. Soya bitkisinin tepe büyüme noktasında farklı gelişme dönemlerinde meydana getirilen mekanik zararın, çeşitlere göre 1000 tohum ağırlığı ve tohum verimine etkilerine ilişkin iki yıllık ortalama değerler ve EGF(\%5)'e göre oluşan gruplar

Table 4. Effects of mechanical damage of the soybean plant in different growth periods at the peak growth point belonging to 1000-seed weight and seed yield per dectare in two years average values groups formed according to the mean values obtained and LSD (5\%)

\begin{tabular}{|c|c|c|c|c|c|c|}
\hline \multirow{3}{*}{ Uygulamalar (B) } & \multicolumn{3}{|c|}{1000 Tohum Ağırlığı (g) } & \multicolumn{3}{|c|}{ Tohum Verimi $\left(\mathrm{kg} \mathrm{da}^{-1}\right)$} \\
\hline & \multicolumn{2}{|c|}{ Çeşitler (A) } & \multirow{2}{*}{ Ort. (B) } & \multicolumn{2}{|c|}{ Çeşitler (A) } & \multirow{2}{*}{ Ort. (B) } \\
\hline & Arisoy & Blaze & & Arısoy & Blaze & \\
\hline Kontrol & $161.5 \mathrm{a}$ & $160.1 \mathrm{a}$ & $160.8 \mathrm{~A}$ & $435.8 \mathrm{c}$ & $425.7 d$ & $430.7 \mathrm{~B}$ \\
\hline$v_{1}$ & $161.4 \mathrm{a}$ & $156.5 \mathrm{~b}$ & $158.9 \mathrm{~B}$ & $518.8 \mathrm{a}$ & $428.2 d$ & $473.5 \mathrm{~A}$ \\
\hline$v_{2}$ & $160.0 \mathrm{a}$ & $152.2 \mathrm{c}$ & $156.1 \mathrm{C}$ & $469.3 \mathrm{~b}$ & $399.4 \mathrm{e}$ & $434.4 \mathrm{~B}$ \\
\hline $\mathbf{V}_{3}$ & $157.1 \mathrm{~b}$ & $152.0 \mathrm{c}$ & $154.5 \mathrm{D}$ & $439.6 \mathrm{c}$ & $389.3 \mathrm{f}$ & $414.4 \mathrm{C}$ \\
\hline Ort.(A) & $160.0 \mathrm{~A}$ & $155.2 \mathrm{~B}$ & & $465.9 \mathrm{~A}$ & $410.6 \mathrm{~B}$ & \\
\hline
\end{tabular}
A: Ö.D; B: 0.70; AxB: 0.99

Ort.: Ortalama; A:Çeşit; B: Uygulamalar; AxB: Çeşit x Uygulama; Ö.D.: Önemli değil.

\section{Protein ve yağ oranı}

íki yıllık ortalama değerlere göre, denemeye alınan soya çeşitlerine ait protein ve yağ oranı değerleri arasında istatistiksel olarak önemli düzeyde farklılıklar saptanmamıştır. Farklı uygulamalara göre denemeye alınan soya çeşitlerine ait ortalama protein oran değerleri \%36.0-36.4 arasında, yağ oranı değerleri ise \%16.5-17.6 arasında değişim göstermiştir. En yüksek protein oranı değeri Blaze çeşidinden elde edilirken, en yüksek yağ oranı değeri de Arısoy çeşidinden elde edilmiştir. Yağlı tohumlardaki yağ oranı ile protein oranı arasında negatif bir ilişki bulunmaktadır. Yağ ve protein oranı bakımından çeşitler arasında önemsiz de olsa meydana gelen farklılık çeşitlerin farklı genetik yapıya sahip olmalarından kaynaklanmaktadır. Bakal ve ark. (2017), Çukurova bölgesinde yaptıkları bir çalışmada protein oranını Arısoy çeşidinde \%37.4, Blaze çeşidinde ise \%36.9 olarak bulmuşlardır. Aynı araştırıcılar, tohumdaki yağ oranını ise Arısoy çeşidinde \%18.6, Blaze çeşidinde ise $\% 18.0$ olduğunu bildirmişlerdir.
Soya bitkisinin tepe noktasında meydana getirilen mekanik zarar, çeşitlerin protein ve yağ oranı değerleri üzerine önemli düzeyde etkili olmamıştır. Yapılan uygulamalara göre, iki yıllık ortalama protein oranı değerleri Arısoy çeşidinde \%35.9-36.1, Blaze çeşidinde ise 36.2-36.8 arasında değişim göstermiştir. Yağ oranı değerleri ise uygulamalara göre, Arısoy çeşidinde \%17.517.9, Blaze çeşidinde ise \%16.2-16.9 arasında değişim göstermiştir. Uygulamalara göre ortalama yağ oranı \%16.8-17.4, protein oranı ise 36.1-36.3 arasında değişim göstermiştir. Bu değerlerin incelenmesinden de görüleceği gibi, farklı büyüme dönemlerinde soya bitkisinin tepe büyüme noktasında meydana getirilen mekanik zarar, tohumdaki yağ ve protein içeriği üzerine etkili olmamıştır. Protein ve yağ oranına etkileri bakımından, çeşitler $x$ uygulamalar arasındaki ilişki istatistiksel olarak önemsiz bulunmuştur. Diğer bir ifadeyle, bitkilerin tepe noktasında meydana getirilen mekanik zarar, çeşitlere ait yağ ve protein oranı üzerine önemli düzeyde etkili olmamıştır (Çizelge 5). 
Çizelge 5. Soya bitkisinin tepe büyüme noktasında farklı gelişme dönemlerinde meydana getirilen mekanik zararın, çeşitlere göre protein ve yağ oranına etkilerine ilişkin iki yıllık ortalama değerler ve EGF(\%5)'e göre oluşan gruplar

Table 5. Effects of mechanical damage of the soybean plant in different growth periods at the peak growth point belonging to oil and protein content in two years average values groups formed according to the mean values obtained and LSD (5\%)

\begin{tabular}{lccccccc}
\hline \multirow{2}{*}{ Uygulamalar (B) } & \multicolumn{3}{c}{ Protein Oranı (\%) } & \multicolumn{3}{c}{ Yağ Oranı (\%) } \\
\cline { 2 - 3 } & \multicolumn{2}{c}{ Çeşitler (A) } & \multirow{2}{*}{ Ort. (B) } & \multicolumn{2}{c}{ Çeşitler (A) } & \multirow{2}{*}{ Ort. (B) } \\
\cline { 2 - 3 } & Arısoy & Blaze & & & Arısoy & Blaze & \\
\hline Kontrol & 36.1 & 36.2 & 36.1 & & 17.9 & 16.9 & 17.4 \\
$\mathbf{V}_{\mathbf{1}}$ & 36.0 & 36.5 & 36.2 & & 17.5 & 16.7 & 17.1 \\
$\mathbf{V}_{\mathbf{2}}$ & 35.9 & 36.8 & 36.3 & & 17.6 & 16.3 & 17.0 \\
$\mathbf{V}_{\mathbf{3}}$ & 36.0 & 36.4 & 36.2 & & 17.5 & 16.2 & 16.8 \\
Ort.(A) & 36.0 & 36.4 & & & 17.6 & 16.5 & \\
\hline
\end{tabular}

EGF (\%5) A: Ö.D.; B: Ö.D.; AxB: Ö.D.

Ort.: Ortalama; A:Çeşit; B: Uygulamalar; AxB: Çeşit x Uygulama; Ö.D.: Önemli değil.

Sonuç olarak, Çukurova bölgesi ikinci ürün koşullarında yetiştirilen soya bitkisinin tepe büyüme noktasında, farklı dönemlerde meydana getirilen mekanik zararın, tohum verimi ile bazı tarımsal özellikler üzerine olan etkilerini belirlemek amacıyla yapılan bu çalışmada Arısoy ve Blaze olmak üzere iki farklı çeşit kullanılmıştır. Farklı dönemlerde soya bitkisinin tepe noktasında meydana getirilen mekanik zararın, uygulama zamanının doğru seçilmesi halinde tohum verimi üzerine artırıcı etkisinin olduğu saptanmıştır. Erken vejetatif gelişme döneminde tepe noktasına (büyüme konisine) verilen mekanik zarar, alt boğumda bulunan tomurcukların sürerek daha fazla yan dal ve bakla oluşturması sonucu verim kaybını minimum düzeyde azaltmıştır. Yapılan bu çalışmada elde edilen sonuçlara göre, ikinci ürün koşullarında yetiştirilen soya bitkisinin dolu zararına maruz kalarak zarar görmesi halinde, bitkinin zarar gördüğü gelişme dönemine göre, tohum veriminin artabileceği veya bazı durumlarda ise verim kayıplarının olabileceği gözlemlenmiştir.

\section{ÖZET}

Amaç: Bu çalışma; Çukurova bölgesi ikinci ürün koşullarında yetiştirilen soya bitkisinin tepe büyüme noktasında farklı dönemlerde meydana getirilen mekanik zararın, tohum verimi ile bazı tarımsal özellikler üzerine olan etkilerini belirlemek amacıyla yapılmıştır.

Yöntem ve Bulgular: Çalışma, 2018 ve 2019 yıllarında, Çukurova Üniversitesi Ziraat Fakültesi, Tarla Bitkileri Bölümü Araştırma Alanında ve ikinci ürün yetiştirme sezonunda yürütülmüştür. Araştırmada; üç farklı vejetatif gelişme döneminde $\left(V_{1}, V_{2}\right.$ ve $\left.V_{3}\right)$ bitkilerin tepe büyüme noktaları koparılarak mekanik zarar meydana getirilmiştir. Materyal olarak, Arısoy (III. Olgunlaşma grubunda) ve Blaze (IV. Olgunlaşma grubunda) çeşitleri kullanılmıştır. Araştırmaya konu olan deneme bölünmüş parseller deneme desenine göre üç tekrarlamalı olarak kurulmuş ve yürütülmüştür.

Genel Yorum: Araştırma sonucu, V1, V2 ve V3 vejetatif gelişme dönemlerinde meydana gelen mekanik zararın, verime üzerine etkilerinin çeşitlere göre farklı olduğu tespit edilmiştir. İki yıllık ortalama değerlere göre, en yüksek tohum verimi, her iki soya çeşidinde de ilk üç yapraklı dönemde $\left(V_{1}\right)$ yapılan uygulamalarından elde edilmiştir (473.5 $\left.\mathrm{kg} \mathrm{da}^{-1}\right)$. Bu dönemde yapılan uygulama Arısoy çeşidinde yaklaşık \%19.0 oranında verim artışına neden olmuştur.

Çalışmanın Önemi ve Etkisi: Farklı dönemlerde soya bitkisinin tepe noktasında meydana getirilen mekanik zararın, uygulama zamanının doğru seçilmesi halinde tohum verimi üzerine artırıcı etkisinin olduğu saptanmıştır. Erken vejetatif gelişme döneminde tepe noktasına (büyüme konisine) verilen mekanik zarar, alt boğumda bulunan tomurcukların sürerek daha fazla yan dal ve bakla oluşturması sonucu verim kaybını minimum düzeyde azaltmıştır. Yapılan bu çalışmada elde edilen sonuçlara göre, ikinci ürün koşullarında yetiştirilen soya bitkisinin dolu zararına maruz kalarak zarar görmesi halinde, bitkinin zarar gördüğü gelişme dönemine göre, tohum veriminin artabileceği veya bazı durumlarda ise verim kayıplarının olabileceği gözlemlenmiştir.

Anahtar Kelimeler: Soya, mekanik zarar, tohum verimi, bitki gelişim dönemi.

\section{TEŞEKKÜR}

Bu çalışma, Çukurova Üniversitesi Fen Bilimleri Enstitüsü'nde 2018 yılında Özge Bağırkan tarafından yürütülen yüksek lisans tezinin bir kısmını kapsamakta 
olup, yazarlar desteklerinden dolayı Çukurova Üniversitesi Araştırma Projeleri Birimi'ne teşekkür ederiz.

\section{ÇIKAR ÇATIŞMA BEYANI}

Yazar(lar) çalışma konusunda çıkar çatışmasının olmadığını beyan eder.

\section{ARAŞTIRMACILARIN KATKI ORANI BEYANI}

Yazarlar çalışmaya eşit oranda katkı sağlamış olduklarını beyan eder.

\section{KAYNAKLAR}

Arıoğlu H (1991) Çukurova koşullarında dolu zararının soya bitkisinde meydana getirdiği verim kaybının belirlenmesi üzerinde bir araştırma. Ç.ü. Ziraat Fakültesi Dergisi 6 (3): 91-102.

Arıoğlu H (2014) Yağ bitkileri yetiştirme ve ıslahı. ç.Ü. Zir. Fak. Yayınları, Genel Yayın No:220, No:A-70. Adana.

Arıoğlu H, Güllüoğlu L (2018) Türkiye'de yağlı tohum üretimi ve yem sektörüne etkileri. Harman Time Dergisi 6(66): 38-42.

Asar M, Yalçın S, Yücel G, Nadaroğlu Y, Erciyas H (2007) Zirai Metoroloji Ders Kitabı. DMi Genel Müdürlüğü Zirai Meteoroloji Şube Müdürlüğü. Ankara.

Aslam M, Naseer AK, Siddique MM (1993) Effect of different row and plant spacings on soybean yield and Its components. Pakistan J. Agric. Res. 14(3): 143-148.

Bakal H, Güllüoğlu L, Onat B, Arıoğlu, H (2017) The effect of growing seasons on some agronomic and quality characteristics of soybean varieties in Mediterranean region in Turkey. Turkish J. of Field Crops 22(2): 187196.

Camery M.P, Weber CR (1953) Effects of certain components of simulated hail injury on soybeans and corn. Research Bulletin (lowa Agriculture and Home Economics Experiment Station): Vol. 31, No. 400.

Conley SP, Pedersen P, Christmas EP (2008) Main-stem node removal effect on soybean seed yield and composition, Crop Sci. Soc. 101(1): 120-123.

Çırak C, Esendal E (2005) Soyada bitki gelişim dönemleri, OMÜ Zir. Fak. Dergisi 20(2): 57-65.

FAO (2019) Tarımsal Yapı ve Üretim Bilgileri. http://www.fao.org/faostat/en/\#data/QC

Fehr WR, Caviness CE, Vorst JJ (1977) Response of Indeterminate and determinate soybean cultivars to defoliation and half-plant cutoff. Crop Science 17(6): 913-917.
Fehr WR, Hicks DR, Hawkins SE, Ford JH, Nelson WW (1983) Soybean recovery from plant cutoff, breakover, and defoliation Agronomy Journal 75(3): 512-515.

Güllüoğlu L, Bakal H, Arıoğlu H (2016) The effects of twinrow planting pattern and plant population on seed yield and yield components of soybean at late double-cropped planting in Cukurova region. Turk. J. Field Crops 21(1): 59-65.

Hintz RW, Fehr WR (1990) Plant density and degoliation effect on the recovery of soybean injured by stem cutoff during vegetative development. Agronomy Journal 82: 57-59.

Lee CD, Zarnstorff ME (2012) Soybean yield loss caused by node removal. Crop Management 11(1): 1-8.

Malone SR, Caviness CE (1985) Cut-off, breah-over, and defoliation effects on a determinate soybean, Agronomy Journal 77: 585-588.

Oba M, Arıoğlu H (2001) Çukurova Bölgesinde 2. ürün olarak yetiştirilen soya bitkisinde, farklı zamanlarda ve oranlarda meydana gelen mekanik zararın, tohum verimine etkisi. Türkiye 4. Tarla Bitkileri Kongresi, 379-384. 17-21 Eylül 2001-Tekirdağ.

Onat B, Bakal H, Gülloğlu L, Arıoğlu H (2017) The effects of high temperature at the growing period on yield and yield components of soybean varieties. Turkish Journal of Field Crops 22(2): 178-186.

Owen LN, Catchot AL, Musser FR, Gore J, Cook DC, Jackson R, Allen C (2013) Impact of defoliation on yield of group IV soybeans in Mississippi. Crop Production 54: 206-212.

Tanner JW, Hume DJ (1978) Soybean manangement and production (hail damage). p.158-216 (Ed. By. A.G. Norman) Academic Press, New York, 269pp.

Teigen JR, Vorst JJ (1975) Soybean Response to Stand Reduction and Defoliation. Agronomy Journal 67(6): 813-816.

TUik (2019) Türkiye İstatistik Kurumu, Tarımsal Bilgiler. http://www.tuik.gov.tr

Yıldırım A, İlker E (2018) Ege Bölgesi'nde ikinci ürün koşullarında bazı soya çeşit ve hatlarının verim ve agronomik özellikleri ile kalite özelliklerinin belirlenmesi. Adnan Menderes Üniversitesi, Ziraat Fakültesi Dergisi 5(2): 1-8. 